\title{
内視鏡的止血術を施行した 十二指腸下行脚からの出血11例
}

\begin{tabular}{|c|c|c|c|}
\hline 坂本直美 ${ }^{1)}$ & 小野里康博 & 飯塚春尚 & 滝沢大地 \\
\hline 大山達也 & 豊田 満夫 & 吉村純彦 & 柿崎 暁 \\
\hline 新井 & 高山 & 小川哲史 & 富澤直樹 \\
\hline 万原 弘 & 阿部 毅彦 & 伊藤秀明 ${ }^{2)}$ & \\
\hline
\end{tabular}

\begin{abstract}
要旨：十二指腸下行脚 (以下, 下行脚) からの出血11例に対し内視鏡的止血術を施行し，そ の有用性を検討した。消化性潰瘍 4 例, 㽞室出血 2 例, 動静脈奇形疑いからの出血 1 例は, 全例クリッピング法，あるいはエピネフリン加高張食塩水(以下，HSE) 局注法との併用に より止血が得られ，その後再出血は認めていない。止血困難例には，先端透明フードを装 着した直視鏡での治療が有用であった。静脈瘤破裂の 2 例のうち，1例目はクリッピング 法による一時止血後に，流出路からアプローチするバルーン閉鎖下逆行性経静脈的塞栓術 (以下，BRTO）を施行したが，術中に再出血をきたし死亡された。2 例目ではヒストアク リル (以下, HA) 局注法による一時止血後に, 流入路から先にアプローチする同時性経静脈 的塞栓術 (以下，DBOE）を施行し，静脈瘤の消失に成功した。十二指晹静脈瘤の破裂症例 に対する interventional radiology（以下，IVR）では静脈瘤内の圧を上昇させないよう，流入 路からアプローチする必要があると考えられた。膵癌浸潤からの出血 1 例はHSE局注法で, 粘膜下腫瘍からの出血. 1 例はクリッピング法で一時止血が得られ待期的な手術が行われた。 上部消化管出血を疑った場合，下行脚までの十分な観察が必要であり，下行脚からの出血 も出血源が同定できれば少なくとも内視鏡的に一時止血は可能であった。下行㑢からの出 血に対しても内視鏡的止血術は有用であると考えられた。
\end{abstract}

〔Key Words〕内視鏡的止血術，十二指腸㮩室出血，十二指腸静脈瘤

\section{はじめに}

近年，内視鏡的止血法の開発，普及により，か つては緊急手術の対象であった上部消化管出血の ほとんどが内視鏡的に止血されている。しかしな がら，十二指腸下行脚からの出血の場合，出血源 の同定が困難であることが多く, 診断, 治療に苦 慮することも少なくない。今回，最近 9 年間で経 験した下行脚からの出血11症例について内視鏡的 止血術の有用性を検討し，当院におけるその治療 法について報告する。

\section{対象と方法}

1996年 1 月から2004年12月までの当院における 上部消化管出血1,396例のうち, 出血源を下行脚に 認めた 11 例 (平均年齢70歳，男性 6 例，女性 5 例) に対し，全例に直視鏡を使用した内視鏡的止血術

"前橋赤十字病院／消化器病センター, 2 )同 / 病理
を施行し，その有用性について検討した。症例の 内訳は消化性潰瘍 4 例, 㮩室出血 2 例, 静脈瘤破 裂 2 例, 原発性膵癌の浸潤 1 例, 粘膜下腫瘍 1 例, 正常粘膜 (動静脈奇形疑い) からの出血 1 例であっ た(Table 1)。

\section{結 果}

消化性潰瘍は 4 例とも露出血管を認めた。 3 例 がHSE局注法とクリッピング法の併用で， 1 例 がクリッピング法のみで止血された。憩室出血の 2 例はともに傍乳頭憩室内に露出血管を認めた。 1 例がHSE局注法とクリッピング法の併用で, 1 例はクリッピング法のみで止血された。動静脈 奇形疑いの 1 例は正常粘膜から湧出性に出血して いたがクリッピング法のみで止血された。これら 7 例は, 全例一度の止血処置で再出血なく経過し ており，内視鏡的止血術により根治できた。 
Table 1 Summary of the 11 cases of bleeding from the second portion of the duodenum experienced in our department.

\begin{tabular}{|c|c|c|c|c|}
\hline 症例 & 出血源 & 治療法 & 透明フード & 転機 \\
\hline $182 \mathrm{M}(2001)$ & 潰曒 (露出血管) & HSE局注+クリッピング & $\mathrm{O}$ & 軽快 \\
\hline $277 \mathrm{M}(2003)$ & 潰痬 (露出血管) & HSE局注+クリッピング & & 軽快 \\
\hline $373 \mathrm{M}(2003)$ & 潰瘍 (露出血管) & クリッピング & & 軽快 \\
\hline $490 \mathrm{~F}(2004)$ & 潰瘍 (露出血管) & HSE局注+クリッピング & $\mathrm{O}$ & 軽快 \\
\hline $565 \mathrm{M}(2000)$ & 秘室(露出血管) & HSE局注+クリッピング & 0 & 軽快 \\
\hline $673 \mathrm{M}(2004)$ & 稪室(露出血管) & クリッピング & 0 & 軽快 \\
\hline $750 \mathrm{M}(2001)$ & 静脈瘤 & 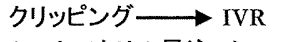 & & 死亡 \\
\hline $8 \quad 47 \mathrm{~F}(2002)$ & 静脈瘤 & ヒストアクリル局注 $\rightarrow I V R$ & & 軽快 \\
\hline $973 \mathrm{~F}(2002)$ & 膵癌浸潤 & HSE局注 $\longrightarrow$ 手術 & 0 & 死亡 \\
\hline $1048 \mathrm{~F}(1996)$ & 粘膜下腫瘍 & 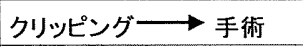 & & 軽快 \\
\hline $1195 \mathrm{~F}(2001)$ & $\begin{array}{l}\text { 正常粘膜 } \\
\text { (AVM疑い) }\end{array}$ & クリッピング & & 軽快 \\
\hline
\end{tabular}

HSE ; hypertonic saline epinephrine solution

IVR ; interventional radiology

AVM ; arterio-venous malformation

静脈瘤破裂は 2 例とも基礎疾患に肝硬変を有し ていた。2 例とも内視鏡的に一時止血が可能で あったが，出血部位の診断と治療に難啮した。

膵癌浸潤からの出血例は不整な周堤を伴う潰瘍 からの出血で, HSE局注法にて一時止血を得た。 診断確定後膵頭十二指腸切除術を施行したが， 3 週間後癌性腹膜炎のため死亡された。粘膜下腫痬 からの出血はクリッピング法による一時止血後, 外科的切除術を施行し, 病理組織学的に平滑筋腫 と診断された。その後の経過は良好である。

\section{症 例}

下行脚からの出血で止血困難例と考えられる悡 室出血と静脈瘤破裂の症例を呈示する。

症例 1

想室出血，65歳，男性。

吐血を主訴に来院。傍乳頭覣室内に露出血管を 認めた。再出血子防のためにHSE局注 ( 4 力所, 計 $4.2 \mathrm{ml})$ 後，直視鏡に透明フードを装着しクリッ ピングを施行した (Color 1)。その後，露出血管 の消失を確認し, 再出血は認めていない。

\section{症例 2}

憩室出血, 73歳, 男性。

下血を主訴に来院。陳旧性脳梗塞にて抗血小板 薬を内服中であった。初回検査時には出血源を同 定できなかったが，再下血時に透明フードを装着 して再検査を行ったところ，傍乳頭想室内に露出
血管認め $($ Color 2$)$, クリッピングを施行した。 2 日後の再検ではクリップは残存し止血されてい た $($ Color 3)。その後再出血は認めていない。

\section{症例 3}

静脈瘤破裂，50歳，男性。

C型肝硬変にて通院中，吐下血を主訴に来院。 来院時の内視鏡検查で，食道および下行脚に静脈 瘤を認めたが出血点は確認できなかった。翌日再 検したところ，下行脚静脈溜上に赤色血栓を認め たためクリッピングを施行した。施行中噴出性の 出血を来たしたが(Color 4), クリッピングの追 加のみで一時止血を得た (Color 5)。その翌日， 静脈瘤に対する根治療法目的のIVRとしてBRTO を施行した。下大静脈への流出路内に逆行性にカ テーテルを挿入しバルーンにて閉塞後, 静脈瘤へ 造影剂を流したところ, 再出血を来たし十二指腸 が造影された(Fig. 1)。経カテーテル的な止血術 に加え, 内視鏡的止血術を試みたが大量出血のた め止血できず死亡された。

\section{症例 4}

静脈瘤破裂，47藏，女性。

B型肝硬変にて通院中, 下血を主訴に来院。来 院時，下行脚に静脈瘤を認めたが出血点を確認で きなかった。 4 日後の再下血時に下行脚静脈瘤か らの出血と確認できたため，HA局注法を行った (Color 6)。3 日後超音波内視鏡にて静脈瘤内の 血栓化を確認できたため (Fig. 2)，待期的に45日 


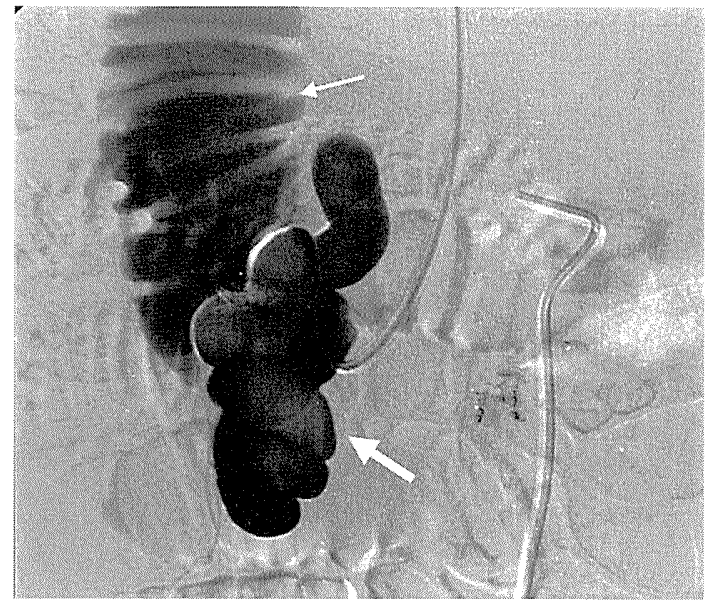

Fig. 1 Leakage of contrast medium to the dodenum (small arrow) from duodenal varices (large arrow) during the varicerography of balloon occluded retrograde transvenous obliteration.

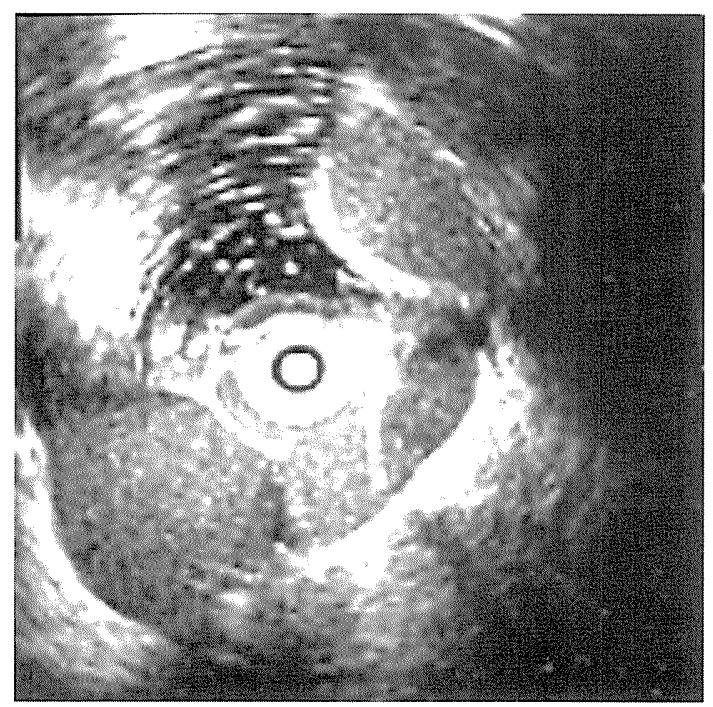

Fig. 2 Endoscopic ultrasonography after the injection of cyanoacrylate to the duodenal varices. The disappearance of the echo-free space was observed.

後に根治療法目的でIVRを施行した。症例 3 の反 省から DBOE (Fig. 3)を選択し, 流入路からアプ ローチした。以後再出血なく, 治療後 4 週で十二 指晹静脈瘤はほぼ消失した。しかし，その後食道 静脈瘤が発達し現在経過観察中である。

\section{考 察}

下行脚からの出血に対する治療法について原因 別に検討した。

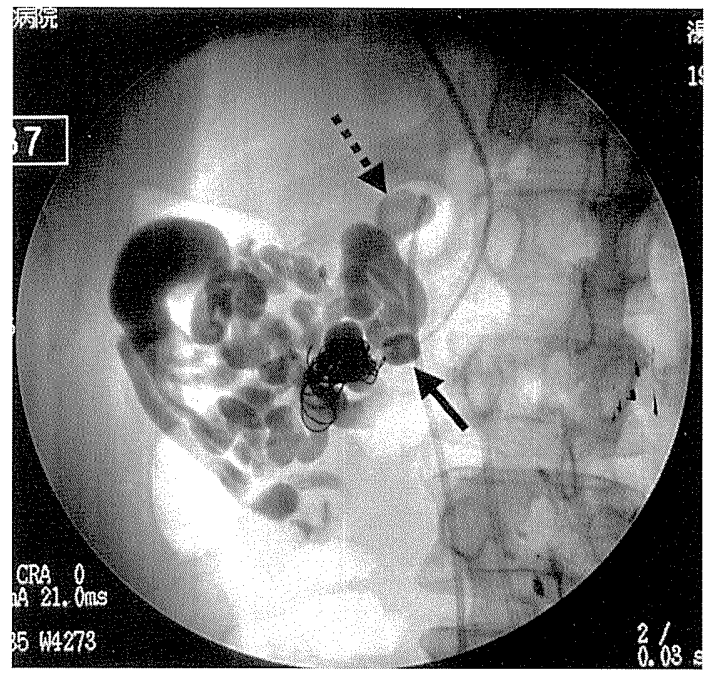

Fig. 3 Blood flow of the feeding vessels was blocked by inflating the balloon (printed arrow) and coils. Blood of the draining vessel was blocked by inflating the balloon (dotted arrow) whole duodenal varices are described.

Table 2 Summary of the reported therapeatic modalities with endoscopy for hemorrhage from diverticulums of duodenum in Japan (1992-2004).

\begin{tabular}{lc}
\hline \multicolumn{1}{c}{ 止血法 } & 例数 \\
\hline クリッピング & $\mathbf{2 4}$ \\
エタノール局注 & 9 \\
HSE局注 & 4 \\
高周波電気凝固 & 4 \\
ポリドカノール局注 & 2 \\
エピネフリン局注 & 1 \\
ゼルフォーム & 1 \\
EVL & 1 \\
YAGレーザー & 1 \\
トロンビン散布 & 1 \\
\hline \multicolumn{1}{c}{ 計 } & $\mathbf{4 8}$ \\
\hline
\end{tabular}

\section{1. 消化性潰痬}

頻度は少ないが下行脚にも消化性潰瘍を認める ことがある。上十二指腸角の肛門側のため内視鏡 操作が難しく, 出血源の同定や治療に苦慮するこ とが少なくない。当院では上部消化管出血の止血 困難例には直視鏡の先端に透明フードを装着して 行なっているが，下行脚の症例も同様に先端透明 フードを使用するのがよいと考えている。また， 止血法は胃や十二指腸球部の消化性潰瘍と同様に, クリッピング法, あるいはHSE局注法との併用 法を第一選択としている。 
Table 3 Previously reported successful therapeutic modalities for duodenal variceal rupture in Japan (1999-2004).

\begin{tabular}{llr}
\hline 止血法 & & 例数 \\
\hline & EVL & 13 \\
& Histoacryl(HA)局注 & 10 \\
Endoscopy & Ethanolamine Oleate(EOI)局注 & 1 \\
& EVL+HA局注 & 4 \\
& EVL+EOI局注 & 3 \\
& Clipping & 2 \\
& Clipping+EVL & 2 \\
\hline \multirow{3}{*}{ IVR } & BRTO & 12 \\
& TIO & 1 \\
\hline Operation & DBOE & 3 \\
\hline Others & & 8 \\
\hline total & & 32 \\
\hline & & \\
EVL: & Endoscopic variceral ligation \\
BRTO: Balloon-oculuded retrograde taransvenous obliteration \\
TIO: & Transleocolic vein obliteration \\
PTO: Percutaneus transhepatic obliteration & \\
DBOE: Dual balloon oculuded embolotheraby
\end{tabular}

今回，4例全例に最終止血が得られ，下行脚の 消化性潰瘍からの出血も, 胃, 十二指腸球部の消 化性潰瘍からの出血と同様に治療できると考えら れた。

\section{2. 十二指腸憩室出血}

十二指腸㮩室は消化管喤室の中で大腸に次いで 頻度が高く, 渋江らは上部消化管内視鏡検査で $2.25 \%$ に認め，高齢になるほど頻度が高率になる と報告している”。その多くは無症状に経過する が，稀に出血をきたすことがある。Palmerら”は， 十二指腸憩室出血の頻度は, 消化管出血の原因の 0.06\%と報告している。出血例に対する治療法は， 以前は外科的手術や動脈塞栓術が中心であったが, 1992年以降内視鏡的止血術が積極的に行われてい る。我々が医学中央雑誌で検索しえた範团内では 1992年 1 月から2004年12月の間に内視鏡的止血術 を施行された十二指腸喤室出血が48例報告されて いる(Table 2)。

当院では直視鏡の先端に透明フードを装着して のクリッピング法を第一選択と考えている。直視 鏡に透明フードを装着すれば，憩室内の観察も可 能であり，また，フード内に開いたクリップを収 納できるため，クリッピングが容易となり有効な 治療法と考えられる。

十二指腸䟤室のほとんどが仮性䟤室であるため, 局注法や電気凝固法などは穿孔，穿通の危険があ
り注意が必要である。しかし，活動性出血があり 出血点の確認が困難な場合や, 処置中に再出血を 来たしやすい露出血管を有している場合は, HSE 局注法の併用も有効と考えており 1 例に施行した。 ただし，局注針は粘膜下層に極力浅く刺し，液量 は 1 回0.5〜 $1 \mathrm{ml}$ にとどめる必要がある。

\section{3. 十二指腸静脈瘤破裂}

十二指腸静脈瘤は比較的稀な病態であり，その 血行動態，成因の多様性のために治療法に一定の 見解は得られていない3。我々が検索しえた範国 内では1999年 1 月から2004年12月までの間に十二 指腸静脈瘤破裂に対し62例（自験例除く）の止血成 功例が報告されている (Table 3)。当院では, 十 二指腸静脈瘤破裂に対しても胃静脈瘤破裂と同様 に，内視鏡により止血が得られた場合でも，再出 血の可能性があるため, 待期的にIVRなどの根治 療法を追加する必要があると考えている。IVRと しては流出路からアプローチするBRTOや, 流入 路からアプローチする経皮経肝門脈側副血行路塞 栓術(以下, PTO), 最近では流入路, 流出路をと もにバルーンカテーテルで閉塞させるDBOEな どがある。しかし，流出路からアプローチする場 合, 静脈瘤内の圧を上昇させ，再破裂をきたす可 能性が考えられるため, 当院では, 流入路からの アプローチがよいと考えている。またクリッピン グ法は胃静脈瘤の一時止血には有効と考えている 
が，十二指腸では接線方向からのアプローチとな

り，クリッピングの効果が不十分となる可能性が あると考えられたため，当院ではHA局注法によ る一時止血を第一選択としている。

\section{4. その他の疾患}

下行脚に出血を来たす疾患としては，今回報告 した, 蓃癌浸潤, 動静脈奇形(疑い), 粘膜下腫瘍 の他にも様々な疾患が考えられるが，内視鏡的に 出血点が確認できれば，胃などからの出血に対す る止血法を応用し, 少なくとも内視鏡的に一時止 血が得られる可能性がある。

\section{おわりに}

上部消化管出血を疑い内視鏡検查を施行する場 合，下行脚までの十分な観察が必要である。また，
先端透明フードを装着することで詳細な観察が可 能となる症例や，止血操作が容易となる症例もあ るので，透明フードの装着は有用であると考えら れる。出血源が同定できれば，適切な止血方法の 選択により少なくとも一時止血が可能であり，下 行脚からの出血に対しても内視鏡的止血術は有用 と考えられた。

文 献

1) 宮川広之, 村島義男, 須賀俊博, 他：傍乳頭㦘室の病態。消 化器内視鏡, 5：1429-35, 1993.

2) Palmer ED : Upper Gastrointestinal Hemorrhage. Charle C Thomas, Springfield, : 6-13, 1970.

3 ）宮島伸宜, 田尼 孝, 山川達郎, 他：十二指腸静脈瘤. 臨床 消化器内科, $15: 1243-1247,2000$.

〈カラーは 1 頁に掲载〉

\section{Study of 11 cases which were performed endoscopic hemostasis for bleeding from the second portion of duodenum}

$\begin{array}{llll}\text { Naomi Sakamoto }^{1)} & \text { Yasuhiro Onozato } & \text { Haruhisa Iizuka } & \text { Daichi Takizawa } \\ \text { Tatsuya Oyama } & \text { Mitsuo Toyoda } & \text { Sumihiko Yoshimura } & \text { Satoru Kakizaki } \\ \text { Hirotaka Arai } & \text { Hisashi Takayama } & \text { Tetsusi Ogawa } & \text { Naoki Tomizawa } \\ \text { Hiroshi Ishihara } & \text { Takehiko Abe } & \text { Hideaki Ito }{ }^{2)} & \end{array}$

1)Department of Gastroenterology, ${ }^{2}$ Department of Pathology Maebasi Red Cross hospital. 